\title{
PENGGUNAAN METODE BELAJAR BERBASIS PROBLEM - BASED LEARNING UNTUK MENAIKAN KETUNTASAN HASIL BELAJAR SISWA PADA PEMBELAJARAN PROGRAM LINEAR DI KELAS XII IPA-1 SEMESTER GANJIL SMA NEGERI 1 PINANGSORI TAHUN PELAJARAN 2017/2018
}

\author{
Merintan D. Hutapea \\ Guru Mata Pelajaran MatematikaSMA Negeri 1 Pinangsori \\ merintan.d@gmail.com
}

\begin{abstract}
There is a trend in the world of adult education is to get back on the idea that the child will learn better if the environment is created for real. Learning will be more meaningful if the child is experiencing its own what is studied, then approach based on the problem( Problem Based Learning ) as an option to turn the classroom so that students are taught with real, thus achieving results optimal learning. This research was conducted in SMA Negeri 1Pinangsori, held on 25 September to 25 November 2017. The research plan used is the class Act (PTK), and the criteria used include research qualitative research. Because the data source directly and using research as a gatherer of primary data. Based on the results of this research show that learning with the method of Problem Based Learning on the subject of Linear Programs can improve ketuntasan learning that is the average value of ketuntasan studied by $86.2275 .23 \%$. The expectations of researchers, hopefully with the experience of researchers can be beneficial for a peers plunge in the world of education.
\end{abstract}

Keywords: Motivation, Learning Outcomes learning, Berbasis Problem Based Learning, Linear Program.

\begin{abstract}
Abstrak
Ada kecenderungan dalam dunia pendidikan dewasa ini untuk kembali pada pembahasan bahwa siswa lebih berhasil jika lingkungan sekolah diciptakan secara nyata. Belajar akan lebih bermakna jika anak mengalami sendiri apa yang dipelajari, maka pendekatan berdasarkan permasalah ( Problem Based Learning ) sebagai pilihan untuk menghidupkan kelas agar siswa belajar dengan sesungguhnya, tercapainya pembelajaran yang baik. Pelaksanaan ini mengambil lokasi di SMA Negeri 1 Pinangsori, dilaksanakan pada tanggal 25 September sampai 25 November 2017. Jenis penelitian yang dilakukan yaitu Penelitian Tindakan Kelas (PTK) dengan mengunakan data penelitian langsung. Pada prinsipnya mengambil sumber pengamatan langsung sebagai sumber data utama dalam peneltian. Setelah melihat penelitian ini terlihat nyata pembelajaran dengan metode Problem Based Learning pada pokok bahasan Program Linear, dapat meningkatkan ketuntasan belajar yaitu nilai rata-rata 75,23 dengan ketuntasan belajar $86,22 \%$. Harapan peneliti, semoga dengan pengalaman peneliti bisa dapat dimanfaatkan bagi rekan-rekan yang terjun di dunia pendidikan.
\end{abstract}

Kata kunci: Motivasi Belajar, Hasil Belajar, Berbasis Problem Based Learning, Program Linear.

PeTeKa (Jurnal Penelitian Tindakan Kelas dan Pengembangan Pembelajaran) $\mid 72$ 


\section{PENDAHULUAN}

Pada saat sekarang ini banyak
pendidik sangat mengeluhkan
rendahnya hasil peserta didik dalam
konsep matematika. Situasi seperti ini
terungkap masih besarnya kesalahan
peserta didik untuk menelaah
pembelajaran matematika pada akhirnya
terjadilah kesalahan pada penyelesaian
pertanyaan yang pada akhirnya
mengakibatkan turunnya prestasi belajar siswa (nilai) terlihat pada ulangan harian, ulangan semester, maupun ujian akhir sekolah, seperti biasanya dalam pelaksanaan proses pembelajaran di kelas pada umumnya guru memberikan tugas (pemantapan) secara kontinu dalam bentuk latihan pemecahan soal.

Dalam tindakannya latihan yang diperoleh hanya sebagian yang dapat menaikkan kemampuan siswa dalam melaksanakan konsep matematika. turunnya nilai pembelajaran dapat dimaksudkan tidak baiknya proses pembelajaran. faktornya dapat berasal dari siswa, guru maupun sarana dan prasarana yang ada, minat dan motivasi siswa yang rendah, kinerja guru yang tidak baik, serta sarana dan prasarana yang kurang menunjang akan menjadi penyebab pembelajaran menjadi kurang baik.

Belajar pada prinsipnya adalah "proses perubahan tingkah laku sebagai akibat dari interaksi antara siswa dengan sumber-sumber atau obyek belajar baik secara sengaja dirancang atau tanpa sengaja dirancang" (Susilana, 2009). Proses belajar itu dapat dimaknai (dilakukan) oleh orang yang sedang belajar. Lain dari pada itu proses belajar juga dapat di lihat oleh orang lain. Belajar yang di hayati oleh seorang pelajar (siswa) ada kaitannya pada kegiatan pembelajaran, yang dilaksanakan oleh pelaku pembelajaran (guru). Di lain sisi, belajar yang di rasakan oleh pembelajar berhubungan pada perkembangan jasmani yang siap tumbuh. Pada bentuk lain, proses belajar yang juga berupa pertumbuhan mental tersebut juga didukung oleh tindakan pendidikan yakni pembelajaran. Persamaan lain, belajar ada hubungannya pada usaha atau rekayasa pembelajar. Dari segi siswa, belajar yang dialaminya sesuai dengan perkembangan jasmani dan perkembangan mental, akan ada hasil belajar sebagai akibat pengiring, selanjutnya, dampak pengiring tersebut akan ada hasil rencana belajar sendiri sebagai dampak kemampuan siswa mengarah kemandirian diri. Dari segi guru, kegiatan belajar siswa merupakan akibat dari tindakan pendidikan atau pembelajaran. Proses belajar siswa tersebut menghasilkan perilaku yang dikehendaki, suatu hasil belajar sebagai dampak pengajaran. (Dimyati \& Mudjiono, 2002).

Nurhadi

dkk,

(2004), "Pembelajaran berbasis masalah dikenal dengan nama lain seperti Project-based Teaching (pembelajaran proyek), Experience-Based Education (pendidikan berdasarkan pengalaman), Authentic learning (Pembelajaran autentik), dan Anchored instructian (pembelajaran berakar pada kehidupan nyata). Posisi guru dalam pembelajaran berbasis masalah yakni membuat masalah, mengajukan masalah tidak dapat dikerjakan tanpa guru memperluas lingkungan kelas yang mungkin menghasilkan pertukaran ide secara terbuka. Melihat garis besar pembelajaran berbasis masalah terdiri dari pemberian kepada siswa keadaan masalah yang asli dan bernilai yang dapat menghasilkan kemudahan kepada siswa untuk melaksanakan penyelidikan dan inquiri. 
Merintan D. Hutapea. Penggunaan Model Pembelajaran Problem...

Fokus belajar matematika lebih diutamakan pada kegiatan dengan tidak melupakan pencapaian tujuan. Kegiatan ini lebih difokuskan pada kegiatan belajar matematika seseorang. Tujuan yang paling penting dalam belajar matematika adalah mengatur langkah pikiran untuk menghasilkan masalah bukan hanya menguasai konsep dan perhitungan walaupun sebagian besar belajar matematika yaitu belajar konsep susunan ketrampilan menghitung dan mengkaitkan konsep-konsep tersebut.

Dengan menerapkan metode problem based learning maka setiap siswa akan selalu terjun secara langsung dalam pembelajaran , sehingga dengan keterkaitan ini pokok bahasan yang dibahas akan selalu ingat dalam pemikirannya dan konsep yang harus dikuasai siswa akan mudah diserap hal ini cocok dengan prinsip learning by doing yang menyatakan bahwa pembelajaran akan mudah dipahami siswa dengan para siswa tersebut ikut aktif dalam pembelajaran.

\section{METODE}

$$
\begin{array}{cccc}
\text { Kegiatan ini } & \text { dilaksanakan di } \\
\text { SMA } & \text { Negeri } & 1 & \text { Pinangsori. }
\end{array}
$$

Dilaksanakan dari bulan September tahun 2017 sampai dengan bulan November tahun 2017, menggunakan jenis perlakuan penelitian tindakan kelas (Classroom Action Research) dengan menerapkan 2 alur siklus.

\section{Subyek Penelitian}

Sumber data dari Penelitian Tindakan Kelas ini adalah siswa kelas Kelas XII IPA 1 SMA Negeri 1 Pinangsori Tahun Pelajaran 2017/2018. Pengangkatan subyek penelitian ini dinilai pada keadaan kelas yang bisa mewakili siswa kelas XII IPA secara keseluruhan, dipilih sebagai objek penelitian disebabkan penulis ingin mencari suatu cara pembelajaran yang baik agar dapat menaikkan pemahaman pokok bahasan program linear untuk para peserta didik.

\section{Jadwal Penelitian}

Pelaksanaan Penelitian Tindakan Kelas ini meliputi 2 siklus yakni masing-masing siklus memerlukan waktu 1 (satu) minggu. Setiap siklus meliputi perencanaan, tindakan, observasi, dan refleksi. Adapun jadwal penelitian yang akan dilakukan adalah :

Tabel 1: Jadwal Penelitian

\begin{tabular}{|c|l|c|c|c|c|c|c|c|c|c|c|c|c|}
\hline \multirow{2}{*}{ NO } & \multicolumn{10}{|c|}{ JENIS KEGIATAN } & \multicolumn{8}{|c|}{ WAKTU PELAKSANAAN } \\
\hline & \multicolumn{2}{|c|}{ SEPTEMBER } & \multicolumn{1}{|c|}{ OKTOBER } & \multicolumn{2}{|c|}{ NOVEMBER } \\
\hline & & I & II & III & IV & I & II & III & IV & I & II & III & IV \\
\hline 1 & $\begin{array}{l}\text { Penyusunan Proposal dan } \\
\text { penyerahan Proposal }\end{array}$ & & & & & & & & & & & & \\
\hline 2 & $\begin{array}{l}\text { Pembuatan Instrumen } \\
\text { Penelitian }\end{array}$ & & & & & & & & & & & & \\
\hline 3 & Siklus I & & & & & & & & & & & & \\
\hline 4 & Siklus II & & & & & & & & & & & & \\
\hline 5 & Analisis Data & & & & & & & & & & & & \\
\hline 6 & Penulisan Laporan & & & & & & & & & & & \\
\hline 7 & Pelaporan PTK & & & & & & & & & & & & \\
\hline
\end{tabular}



Merintan D. Hutapea. Penggunaan Model Pembelajaran Problem...

Tehnik dan Alat Pengumpul Data

Pada penelitian tindakan kelas ini untuk tehnik pengumpulan data dilakukan berbagai cara antara lain :

a) Cara Tes Tertulis

Pada tes tertulis disini digunakan sebagai mengumpulkan data siswa tentang hasil pengusaan materi program linear yang dipahami siswa , setelah siswa mengikuti suatu proses perlakuan yang dilakukan oleh peneliti, sehingga diperoleh hasil yang tepat dan dapat mencerminkan secara nyata kemampuan siswa dalam menguasai materi program linear tersebut.

b)Alat Pengumpul Data.

Agar dapat melihat kemampuan yang dikuasai siswa dalam penguasaan materi yang dibuat objek penelitian ini, peneliti menerapkan alat yang berupa tes tertulis yang telah dibuat oleh peneliti sesuai dengan tujuan yang telah tertuang didalam kisi kisi soal .

\section{Indikator Keberhasilan}

Pada Prinsipnya penelitian tindakan kelas ini terpenuhi sesuai dengan harapan jika dalam penelitian yakni :

1) Penguasaan materi program linear Kelas XII IPA 1 SMA Negeri 1 Pinangsori, Di akhir penelitian ini meningkat dengan mencapai $90 \%$ siswa telah memenuhi nilai diatas batas ketuntasan minimal (KKM ).

2) Penggunaan metode problem based learning merupakan cara yang baik untuk menerapkan materi program linear, pada hal ini dilihat dengan kenaikan hasil nilai yang diperoleh masing - masing siswa.

\section{Langkah Penelitian Tiap Siklus}

Sebelum melaksanakan tindakan pada kegiatan ini, terlebih dahulu peneliti membuat observasi cara mengajar guru dalam kelas serta mengumpulkan data kemampuan awal penguasaan pokok bahasan program linear dari siswa.

Pada penjelasan sebelumnya bahwa pada penelitian tindakan kelas ini dilakukan dalam 2 siklus namun bila dari dari dua siklus yang direncanakan masih terdapat masalah yang harus dipecahkan sehingga dapat dilanjutkan dengan siklus berikutnya. Pelaksanaan prosedur penelitian yang akan dilakukan oleh peneliti adalah antara lain :

\section{Siklus I}

Tahap perencanaan tindakan

Pada tahap perencanaan tindakan pada siklus ini, kegiatan yang dilakukan antara lain :

1) Penulis membuat silabus yang berkaitan dengan materi program linear.

2) Penulis merancang strategi pembelajaran yang dapat merangsang keaktifan siswa.

3) Membuat alat pengumpul data yakni berupa tes dan diperuntukkan untuk memperoleh pemahaman kemampuan siswa yang berkaitan dengan materi program linear.

\section{Tahap pelaksanaan tindakan}

1) Untuk siswa diberikan penjelasan umum tentang tujuan penelitian tindakan kelas ysng cocok dengan rancangan yang telah ditentukan, baik terkait pengumpulan data maupun kegiatan - kegiatan yang lain.

Proses dalam penelitian tindakan kelas ini meliputi : (a) Memberikan penjelasan secara umum tentang materi yang disampaikan dengan mengunakan metode problem based learning dengan cara menstimulir rasa ingin tahu siswa (b) Mendukung siswa yang belum aktif agar aktif 
dalam mengikuti pembelajaran. (c) Melihat dan mencatatat siswa yang berpartisipasi aktif dalam pembelajaran (d) Mengumpulkan hasil pengujian yang diperoleh siswa dalam mengerjakan tugas (e) Menganalisis hasil tes yang diperoleh setelah siswa belajar dengan metode Program Based Learning.

2) Penulis menyampaikan sesuai dengan strategi pembelajaran klasikal yang telah dibuat dan mencatat kegiatan - kegiatan yang dilakukan oleh masing - masing siswa.

3) Penulis melaksanakan evaluasi pada siswa untuk memperoleh pemahaman siswa terkait dengan materi program linear.

\section{Tahap observasi tindakan}

Peneliti mengamati dan mencatat semua kejadian yang terjadi pada saat siswa mengikuti pengajaran dan menanyakan pada siswa yang kurang aktif dalam pembelajaran tentang kesulitan-kesulitan yang dihadapinya.

\section{Tahap refleksi}

Penulis mengamati hasil pekerjaan siswa dan hasil observasi yang dilaksanakan pada siswa guna menentukan cara berikutnya. Penulis membuat pengelompokkan siswa didasarkan pada hasil yang diperoleh siswa pada evaluasi yang dilaksanakan.

\section{Siklus II}

\section{Tahap perencanaan tindakan}

1) Membuat fasilitas dan sarana yaitu dengan menentukan kelompok siswa dengan membagi siswa yang menguasai materi awal yaitu materi yang telah disampaikan pada siklus I.

2) Menentukan perangkat pada masing-masing kelompok meliputi fasilitator, pencatat, juru bicara dan pengatur waktu.

3) Menentukan materi yang akan disampaikan pada masing - masing kelompok untuk didiskusikan.

\section{Tahap pelaksanaan tindakan}

1) Penulis mencontohkan penjelasan tentang materi program linear yang ingin disampaikan serta menjelaskan kegiatan yang akan dilaksanakan berkaitan dengan pengajaran dalam tehnik merangsang siswa untuk belajar bersama dalam kelompok.

2) Siswa yang telah menguasai pada materi awal di siklus I diminta membawa pembahasan materi yang diberikan penulis. materi yang disampaikan terkait tugas memecahkan masalah tindak lanjut pada siklus I.

3) Memberikan waktu pada masing masing kelompok untuk menampilkan hasil diskusi.

4) Mengkaji materi ajar yang siswa dalam satu kelas mengalami kesulitan ataupun salah dalam apersepsinya.

5) Melakukan evaluasi pada siswa untuk memperoleh kemampuan siswa dalam menguasai pengerjaan soal integral.

\section{Tahap observasi tindakan}

1) Penulis mendata hasil-hasil yang diperoleh siswa serta mencatat kesalahan - kesalahan yang dilakukan siswa dalam mengerjakan masalah yang terkait dengan materi yang disampaikan.

2) Penulis mendata kesalahan kesalahan yang dilakukan siswa dalam menyelesaikan masalah pada materi yang disampaikan.

\section{Tahap refleksi}

Penulis melakukan inventarisasi kesulitan yang dilakukan siswa dalam 
Merintan D. Hutapea. Penggunaan Model Pembelajaran Problem...

menyelesaikan masalah pada materi yang diberikan serta mendata siswa yang telah mampu menyelesaikan soal evaluasi dan mampu memperoleh nilai diatas kriteria ketuntasan belajar (KKM)

\section{HASIL DAN PEMBAHASAN}

\section{Deskripsi Awal}

Jika sebelum penelitian tindakan kelas ini dilakukan, terlebih dahulu penulis melakukan observasi dan pengumpulan data dari keadaan awal kelas yang akan diberi perlakuan , yaitu Kelas XII IPA 1 SMA Negeri 1 Pinangsori Tahun Pelajaran 2017/2018.

Informasi awal ini perlu diketahui agar kiranya penelitian ini sesuai dengan apa yang direncanakan oleh peneliti, apakah benar adanya kelas ini perlu diberikan tindakan yang cocok dengan apa yang akan diteliti oleh penulis yakni penerapan metode problem based learning untuk menaikkan efektifitas pembelajaran materi program linear.

Dengan mengetahui keadaan awal dari kelas yang menjadi objek tindakan kelas ini maka penulis melaksanakan langkah - langkah antara lain :

\section{Perencanaan}

Dengan mengetahui kondisi awal dari Kelas XII IPA 1 SMA Negeri 1 Pinangsori Tahun Pelajaran 2017/2018, Oleh sebab itu penulis merencanakan observasi langsung pada pengajaran yang dilakukan oleh guru pengajar matematika disaat mengajarkan materi pertidaksamaan linier dengan 2 variabel.

Observasi langsung pada pengajaran yang dilaksanakan oleh guru dilakukan untuk mendapatkan strategi pembelajaran yang dilakukan oleh guru pengajar saat melakukan materi pertidaksamaan linier dengan 2 variabel.

\section{Pelaksanaan}

Dalam Pelaksanaan untuk menilai kemampuan awal siswa, di awali dengan pengajaran yang dilakukan oleh guru Pengajar Matematika kelas Kelas XII IPA 1 SMA Negeri 1 Pinangsori, yang mengajarkan pertidaksamaan linear dengan 2 variabel dengan menggunakan metode ceramah. Pada pembelajaran ini peneliti mengamati kejadian - kejadian yang terjadi secara rinci pada saat guru menguraikan materi pertidaksamaan linear dengan 2 variabel.

Pada penyampaian materi pertidaksamaan linear dengan 2 variabel guru membutuhkan waktu 1 jam pelajaran dan 15 menit untuk memberikan contoh, selanjutnya guru memberikan post test dengan mengambil soal yang telah dibuat sebelumnya.

Dalam pelaksanaan ini penulis dan guru pengajar bersama - sama mengawasi kinerja siswa dalam membahas soal yang diberikan , sehingga keakuratan dari hasil pengawasan dapat dipertanggung jawabkan. Pada pelaksanaan post test ini siswa menyelesaikan soal yang diberikan selama 30 menit.

\section{Hasil Pengamatan}

Melihat observasi yang dilakukan oleh penulis didapatkan bahwa pada pengajaran yang dilaksanakan, guru masih menggunakan cara pengajaran yang biasa yaitu guru sebagai agent pembelajaran dan pengajaran materi pertidaksamaan linear dengan 2 variabel tersebut diajarkan dengan menggunakan metode ceramah. Pada pembelajaran berlangsung terlihat siswa asyik dengan kegiatannya sendiri yang tidak ada 
kaitannya dengan apa yang disampaikan guru. Justru masih terlihat siswa yang bermain-main dengan temannya tanpa memperhatikan apa yang diajarkan oleh guru pengajar.

Melihat dari hasil pengerjaan siswa pada alat tes yang telah dirancang oleh guru setelah diadakan penilaian maka didapatkan hasil yang kurang diharapkan.

Dari hasil penilaian tes awal dari 28 siswa didik yang ada di kelas tersebut didapatkan hasil, 5 siswa memperoleh nilai kurang dari 60,9 siswa memperoleh nilai antara 60 hingga 70 , sedangkan siswa yang telah tuntas atau memperoleh nilai di atas batas ketuntasan minimal ada 15 siswa . Dari paparan hasil nilai yang didapatkan siswa maka terlihat bahwa yang mencapai ketuntasan belajar hanya $51.73 \%$

Tabel 2: Presentase Nilai Matematika Kelas XII IPA 1

\begin{tabular}{ccc}
\hline Range Nilai & $\begin{array}{c}\text { Jumlah } \\
\text { Siswa }\end{array}$ & $\boldsymbol{\%}$ \\
\hline$<60$ & 5 & 17,24 \\
$60-70$ & 9 & 31,03 \\
$>70$ & 15 & 51,73 \\
\hline Total & $\mathbf{2 9}$ & $\mathbf{1 0 0}$ \\
\hline
\end{tabular}

\section{Refleksi}

Gambaran kondisi awal yang ada tersebut maka perlu diadakan suatu tindakan untuk mengangkat kemampuan penguasaan materi program linear dari siswa Kelas XII IPA 1 SMA Negeri 1 Pinangsori.

Berdasarkan tanya jawab yang dilakukan peneliti terhadap siswa,, terdapat bahwa siswa mempunyai ketidakmampuan pada pengembangan kemampuan (skill) pengerjaan suatu masalah program linear karena kurangnya siswa diberi kesempatan untuk berlatih dalam menuntaskan masalah - masalah, sehingga siswa tuntut untuk diberi kesempatan untuk menyelesaikan masalah sebelum guru pengajar menyelesaikannya.

Beranjak dari keadaan awal tersebut maka penulis merencanakan tindakan penelitian dengan melakukan metode problem based learning pada pembelajaran materi program linear di kelas XII IPA 1 dengan melakukan pembelajaran aktif .

\section{Siklus I}

\section{Perencanaan}

Untuk melaksanakan penelitian pada siklus I ini penulis perlu merencanakan tindakan antara lain :

1) Merancang silabus materi pembelajaran program linear.

2) Membuat susunan program pengajaran yang diperuntukkan untuk pengajaran pada kelompok besar. Rancangan program yang dibuat digunakan untuk pengajaran 2 x 45 menit dengan rincian (1) apersepsi 10 menit (2) Kegiatan inti berisi pengerjaan lembar kerja dan mengaktifkan siswa dengan metode tanya jawab selama 40 menit (3) Penutup 5 menit (4) evaluasi 35 menit

3) Membuat lembar kerja ( LKS ) siswa yang diperuntukkan untuk mengaktifkan siswa dalam belajar dengan penyusunan langkah demi langkah yang mengarahkan siswa dalam mendapatkan masalah atau penyelesaian suatu masalah.

4) Merancang alat evaluasi yang digunakan untuk memperoleh data kemampuan siswa setelah melakukan tindakan dengan menggunakan metode problem based learning yang diperuntukkan untuk kelompok besar

5) Menrancang solusi dan tahap untuk disampaikan pada siswa berhubungan kelemahan siswa 
Merintan D. Hutapea. Penggunaan Model Pembelajaran Problem...

dalam menuntaskan masalah yang telah di test oleh guru pengajar.

\section{Pelaksanaan Tindakan}

Dalam pelaksanaan tindakan

siklus I penulis melakukan kegiatan sesuai dengan apa yang telah ditetapkan, dimulai dengan menjelaskan pada siswa tentang proses yang harus dilakukan oleh siswa dalam mengikuti kegiatan.

Penulis membagikan lembar kerja ( LKS ) yang telah dibuat oleh penulis untuk dikerjakan siswa secara keseluruhan dan penulis berkeliling untuk mengamati cara kerja siswa serta membantu siswa yang mengalami masalah dalam menyelesaikan lembar kerja yang dibagikan.

Dalam pelaksanaan menyelesaikan lembar kerja siswa terlihat beberapa siswa saling berkomunikasi dengan teman terdekatnya tentang cara penyelesaian dari lembar kerja yang dibagikan.

Sambil berkeliling penulis menulis masalah yang terjadi pada saat siswa mengerjakan lembar kerja tersebut selain itu penulis juga menulis nama siswa yang aktif dan mampu dalam menyelesaikan masalah yang diberikan oleh penulis.

Penulis menugaskan pada siswa yang telah mampu memecahkan masalah yang masih menjadi permasalahan pada sebagian besar siswa , untuk dijelaskan pada temannya cara memecahkan masalah tersebut.

Di akhir pembelajaran yaitu 35 menit terakhir dari pembelajaran peneliti memberikan post test yang harus diselesaikan oleh seluruh siswa secara individual.

\section{Hasil Pengamatan}

Setelah lembar kerja yang mengarahkan siswa untuk menemukan suatu masalah program linear dibagikan maka tampak siswa keinginan dalam mengerjakan lembar kerja tersebut.

Dalam pengerjaan lembar kerja yang dibagikan ini tak terlihat adanya siswa yang tidak aktif ataupun asyik mengerjakan pekerjaan yang lain, semuanya asyik dalam mengerjakan lembar kerja yang dibagikan.

Pada pelaksanaan pengerjaan lembar kerja tersebut tampak adanya siswa yang mengalami hambatan dalam menyelesaikan bertanya pada teman terdekatnya , namun ada pula siswa yang mengalami hambatan dalam mengerjakan lembar kerja tersebut langsung bertanya kepada penulis dan guru pengajar. Pada pengerjaan lembar kerja ditemukan siswa yang belum memahami konsep dasar membuat model matematika pada pokok bahasan program linear.

Pada post test yang ditugaskan setelah diperiksa oleh guru pengajar dan peneliti diperoleh hasil sebagai berikut : Dari 29 siswa yang ada , 3 siswa memperoleh nilai kurang dari 60,7 memperoleh nilai antara 60 hingga 70 , sedangkan siswa yang telah tuntas atau memperoleh nilai di atas batas ketuntasan minimal ada 19 siswa, hal ini berarti $65,52 \%$ siswa telah mampu memahami konsep dasar program linear.

Tabel 3: Presentase Nilai Matematika Kelas XII IPA 1 pada siklus 1

\begin{tabular}{ccc}
\hline Range Nilai & Jumlah Siswa & $\mathbf{\%}$ \\
\hline$<60$ & 3 & 10,34 \\
$60-70$ & 7 & 24,14 \\
$>70$ & 19 & 65,52 \\
\hline Total & $\mathbf{2 9}$ & $\mathbf{1 0 0}$ \\
\hline
\end{tabular}

\section{Refleksi}

Pada melihat titik lemah yang terjadi pada sebagian kecil siswa berkenaan konsep dasar program linear maka perlu diadakan penjelasan yang 
mendasar pada anak - anak yang mengalami hambatan dengan memanfaatkan teman yang telah memahami konsep dasar program linear tersebut untuk menjelaskannya.

Pendataan siswa yang punya kemampuan lebih dan mampu untuk menyampaikan materi yang dipahaminya kepada temannya.

Pentingnya dibentuk kelompok - kelompok kecil yang terdiri dari 3 siswa. untuk berkolaborasi pada belajar dan dipimpin oleh anak yang punya kemampuan lebih dan mampu menyampaikan materi yang dikuasainya.

\section{Siklus II}

\section{Perencanaan}

Dalam perencanaan siklus II ini peneliti dan guru merencanakan tindakan antara lain :

a) Menetapkan kelompok kecil yang terdiri dari 4 anak dan masing masing kelompok dipimpin oleh anak yang dipilih dari anak yang punya kemampuan lebih dan mampu memimpin.

b) Menetapkan rancangan pembelajaran materi program linear sub bahasan persamaan program linear sederhana untuk kelompok kecil yang dipergunakan bagi pengajaran selama 90 menit.

c) Merancang daftar lembar kerja yang dipergunakan untuk diskusi kelompok

d) Merencanakan alat evaluasi yang berupa soal tes yang digunakan untuk menguji kemampuan siswa.

\section{Pelaksanaan Tindakan}

Terlihat yang telah direncanakan maka penulis melaksanaan tindakan siklus II dengan materi bahasan persamaan program linear sederhana, pada tindakan di siklus II ini diawali penjelasan kepada siswa tentang prosedur yang akan dilaksanakan pada pembelajaran untuk kelompok kecil.

Penulis menentukan kelompok yang terdiri dari 4 siswa dan menentukan ketua dari masing - masing kelompok tersebut, selanjutnya siswa berkumpul menurut kelompok masing masing.

Dimana siswa telah berkumpul dengan kelompoknya maka penulis membagikan lembar kerja siswa untuk didiskusikan bersama dari masing masing kelompok, pada saat siswa mulai berdiskusi peneliti berkeliling untuk menulis kesalahan - kesalahan yang dilakukan kelompok untuk dibimbing serta menulis siswa - siswa yang kurang aktif agar bisa diajak aktif oleh kelompoknya.

Setelah waktu yang ditentukan pada lembar kerja selesai maka peneliti meminta perwakilan kelompok untuk mempresentasikan hasil kerjanya dan kelompok lain diminta menanggapi apa yang telah dipresentasikan, pada kesempatan ini peneliti memimpin jalannya diskusi dan bersama - sama siswa menentukan jawaban.

Untuk jam pertemuan selanjutnya siswa dilakukan evaluasi tentang penguasaan materi persamaan program linear sederhana dalam waktu 1 jam pelajaran atau 45 menit

\section{Hasil Pengamatan}

Dalam pelaksanaan siklus II ini tampak sekali bahwa siswa sangat respon dalam menyelesaikan tugas kelompok, semua siswa terlihat aktif bersama kelompoknya dalam menyelesaikan lembar kerja yang telah diberikan penulis.

Pada saat diskusi pembahasan materi yang diberikan satu kelompok untuk ditanggapi oleh kelompok lain, terkadang terlihat perbedaan pada cara berfikir dari masing - masing siswa 
Merintan D. Hutapea. Penggunaan Model Pembelajaran Problem...

dalam menyampaikan cara pemecahan masalah yang diberikan.

Tabel 4: Presentase Nilai Matematika Kelas XII IPA 1 pada siklus 2

\begin{tabular}{ccc}
\hline Range Nilai & Jumlah Siswa & \% \\
\hline$<60$ & 2 & 6,89 \\
$60-70$ & 2 & 6,89 \\
$>70$ & 25 & 86,22 \\
\hline Total & $\mathbf{2 9}$ & $\mathbf{1 0 0}$ \\
\hline
\end{tabular}

Melihat evaluasi yang dilaksanakan setelah diperiksa diperoleh hasil yang sesuai dengan indikator pencapaian hasil yang diharapkan karena dari 29 siswa yang ada dalam kelas XII IPA 1 tersebut hanya terlihat 4 siswa yang mendapatkan nilai dibawah batas ketuntasan minimal ( KKM ), jadi prosentasi siswa yang telah tuntas adalah $86,22 \%$.

\section{Refleksi}

Melihat hasil evaluasi yang diberikan selama 1 jam pelajaran atau
45 menit tenyata 25 siswa telah mampu mendapatkan nilai di atas batas ketuntasan minimal namun masih terlihat kesalahan yang dibuat oleh siswa dikarenakan faktor kekurang telitian siswa dalam bekerja.

Masalah skill dan kecermatan dalam mengambil langkah pengerjaan masih perlu diperhatikan sehingga penguaasaan materi program linear dapat lebih baik lagi.

Keaktifan dari siswa secara keseluruhan telah sesuai yang diharapkan oleh penulis sebab dalam menyelesaikan lembar kerja secara kelompok ini $99 \%$ telah aktif dalam pembahasan lembar kerja yang diberikan.

\section{Perbandingan antar Siklus}

Beranjak dari hasil pelaksanaan tindakan mulai pemantauan keadaan awal hingga pelaksanaan tindakan pada siklus II maka dapat diuraikan seperti Tabel 5.

Tabel 5: Presentase Nilai Matematika Kelas XII IPA - 1 antar Siklus

\begin{tabular}{|c|c|c|c|c|}
\hline \multirow{2}{*}{ No } & \multirow{2}{*}{ Indikator } & \multicolumn{3}{|c|}{ Porsentasi Ketercapaian } \\
\hline & & Pra siklus & Siklus I & Siklus II \\
\hline 1 & $\begin{array}{l}\text { Peserta Didik mampu mencari HP dari } \\
\text { pertidaksaan linear dengan } 2 \text { variabel }\end{array}$ & $51,73 \%$ & $68,97 \%$ & $90,33 \%$ \\
\hline 2 & $\begin{array}{l}\text { Peserta didik mampu menentukan } \\
\text { model matematika dari suatu masalah } \\
\text { program linier }\end{array}$ & & $65,52 \%$ & $85,33 \%$ \\
\hline 3 & $\begin{array}{l}\text { Peserta didik mampu menerapkan } \\
\text { model matematika untuk menuntaskan } \\
\text { terhadap permasalahan program linier }\end{array}$ & & & $86,22 \%$ \\
\hline
\end{tabular}




\section{SIMPULAN}

Terlihat dari tabel pada siklus tampak adanya hasil dari masing masing indikator yang harus dipahami peserta didik setelah dilakukan tindakan terjadi peningkatan yang signifikan. Peningkatan hasil pemahaman materi program linear ini bila dilihat dari tindakan yang dilaksanakan telah sesuai dengan pendapat Vygotsky, aktivitas kalaboratif (gabungan) di antara anakanak akan mendukung dan membantu dalam pertumbuhan mereka, karena peserta didik yang seusia lebih suka bekerja dengan orang yang satu zone (zone of proximal development, zpd) dengan yang lain, artinya proses muncul ketika ada keterikatan antar sesama anggota kelompok yang seusia.

Pada prinsipnya anak nyaman dalam belajarnya maka akan tercapai hasil belajar yang diinginkan. Melalui hal ini sebagian besar aktivitas pembelajaran terkonsentrasi pada siswa, yakni mempelajari materi pembelajaran, berdiskusi untuk menyelesaikan masalah atau tugas. Dengan hubungan yang efektif memungkinkan semua anggota kelompok mampu memahami materi pada tingkat yang sama.

\section{DAFTAR PUSTAKA}

Arikunto, Suharsimi, dkk. 2015. Penelitian Tindakan Kelas. Jakarta: Bumi Aksara.

Dimyati dan Mudjiono. 2002. Belajar dan Pembelajaran. Jakarta: Rineka Cipta

Nurhadi dan sentuk ,Agus , Gerrad. 2004. Pembelajaran Kontektual dan Penerapannya Dalam KBK. Malang: UM press.

Nana Sudjana. 2009. Penilaian Hasil Proses Belajar Mengajar. Bandung: PT Remaja Rosdakarya.

Susilana, Rudi, 2009, Media Pembelajaran. Bandung: CV WACANA PRIMA. 